\title{
On the Tectonics of the Western Himalaya
}

\author{
by Michael P. Searle
}

\begin{abstract}
Exciting new data on the Karakoram, Himalayan and Trans-Himalayan mountain are influencing current ideas on the evolution of the India-Eurasia collision and the ensuing Himalayan orogeny. This chronological account starts with the closure of Neo-Tethys, continues through the mid-Tertiary climax of the Himalayan orogeny with widespread magmatism and crustal compression, and ends with Quaternary and present tectonic activity in the western Himalaya and Trans-Himalaya.
\end{abstract}

\section{The Himalayan Region}

Eight major mountain belts radiate outwards from central Asia (Fig. 2): to the north, the Pamirs and the Tien Shan in the U.S.S.R., to the nor theast, the Kun Lun in central China, and to the southwest, the Hindu Kush along the AfganistanPakistan border. In northern Pakistan and the northwestern Indian state of Ladakh, the Karakoram forms the most spectacular mountain range of all - "the world's greatest museum of granite shape and form." The Himalaya ("the abode of snow") itself comprises a series of distinct mountain chains, from north to south - the Ladakh, Zanskar and High or Greater Himalayas, and the Pir Panjal. The highest mountains in the $2500 \mathrm{~km}$-long chain are situated along the northern borders of Pakistan, India, Nepal and Bhutan, creating a formidable geographic barrier between the Indian subcontinent and the Tibetan (Qinghai-Xizang) plateau.

The Himalaya, often taken as the type example of a continent-continent collision zone, can be broadly divided (Fig. 2) into six major geotectonic units (Gansser, 1964). From nor th to south these are the Trans-Himalayan granite batholith (Ladakh and Kangdese plutonic complexes), the Indus-Tsangpo suture zone, the Tibetan-Tethys shelf carbonates (Zanskar, Spiti, Annapurna Himalaya), the Central crystalline complex of the High Himalaya, the Lesser Himalayan sedimentary and volcanic rocks overlain by thrust sheets of inverted metamorphic rocks, and the Siwalik sediments of the subHimalayan zone.

\section{Research Programs in the Himalaya}

Until about 10 years ago, geological interpretations of the western Himalaya were based on a few early accounts of intrepid explorers who had managed to penetrate beyond the hill-stations scattered along the foothills. The most important pioneering work was accomplished by Eric Norin (1946) in Tibet, Arnold Heim and Augusto Gansser (1939) in the Himalaya, Ardito Desio (see Desio, 1979) in the Karakoram, and D.N. Wadia (1953) in the Indian Himalaya.

Since the opening of the Karakoram and Ladakh to foreigners in the mid-1970s, and the establishment of the Chinese Academia Sinica exchange programs in Tibet, geological research has expanded enormously. As a result of field excursions in Tibet, several English language syntheses of Chinese geology have become available (Bally et al., 1980; Shackleton, 1981). Following extensive work by Pakistani geologists, a joint field project involving British geologists and Peshawar University in the Kohistan-Karakoram area was also initiated (Tahirkheli and Jan, 1979; Coward et al., 1982).

In northern India mapping by geologists from the Geological Survey of India and the Wadia Institute of Himalayan Geology (e.g. Gupta and Kumar, 1975; Shah et al., 1976; Srikantia and Razdan, 1980; Thakur, 1981) has been supplemented by several reconnaissance trips by Swiss, Austrian and British geologists (e.g. Frank et al., 1977; Fuchs, 1979; Honegger et al., 1982; Searle, 1983). A joint project between the Wadia Institute and Memorial University of Newfoundland is now

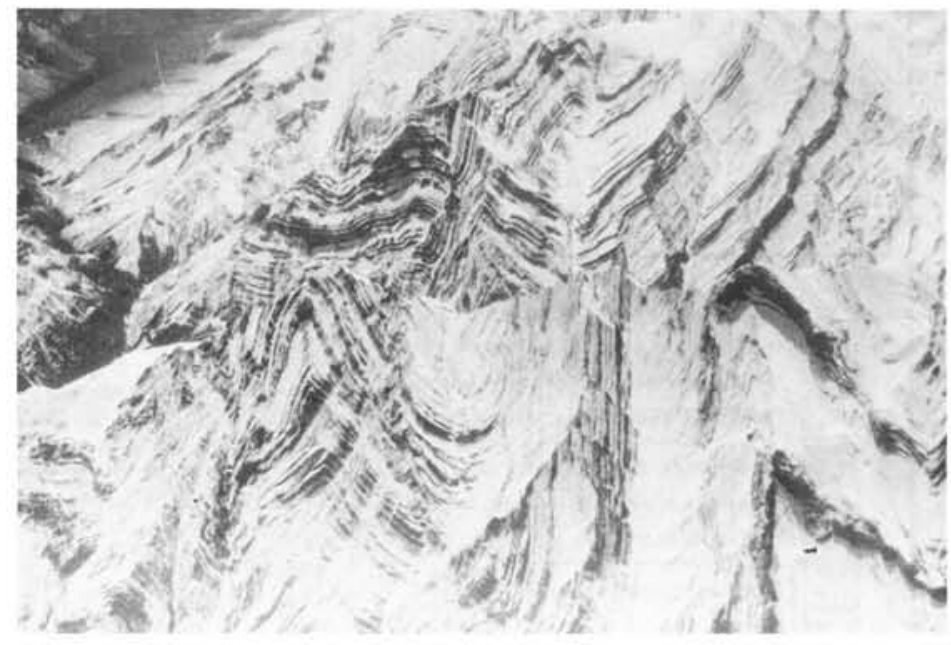

Figure 1: Aerial photograph of large scale folds in Upper Palaeozoic and Mesozoic sediments of the Tibetan-Tethys zone. The Spiti Valley is in the upper left hand corner, some $2000 \mathrm{~m}$ below the mountain crests.

combining mapping with detailed structural transects, geo chemistry, and isotope geochronology studies of volcanic and granitoid rocks. The wealth of new data generated by all these field parties makes the evolution of the Himalayan orogeny one of the most fascinating studies in the geological sciences today.

\section{Evolution of the Himalayan Tethys}

During late Palaeozoic and Mesozoic time, the evolution of the Tibetan-Tethys zone, extending from the Zanskar-Spiti mountains eastwards to northern Nepal and southern Tibet, appears to have been broadly similar to that of well-known Tethyan areas of the Middle East. Rifting of Gondwana occurred initally during the Permian with eruptions of the Panjal volcanic group in Kashmir and Zanskar, and by Triassic time a passive margin with a distinctive continental shelf, slope and basin were already established.

Despite intense folding and thrusting during the Tertiary Himalayan orogeny (Fig. 1), a complete Mesozoic shelf stratigraphy can be recognized. Carbonate sedimentation occurred throughout the Triassic and early Jurassic, with a deepening event in the late Jurassic shown by the richly fossiliferous Spiti shales. Shallow-marine limestones and sandstones deposited in the early and middle Cretaceous pass upward to deeper water shale and "flysch" of the Kangi-la Formation. (Fuchs, 1979). As shown in Figure 3, this deepening event probably coincided with obduction of the Spontang ophiolite (Fig. 4) southwards onto the northern continental margin of India during the late Cretaceous (Searle, 1983). 


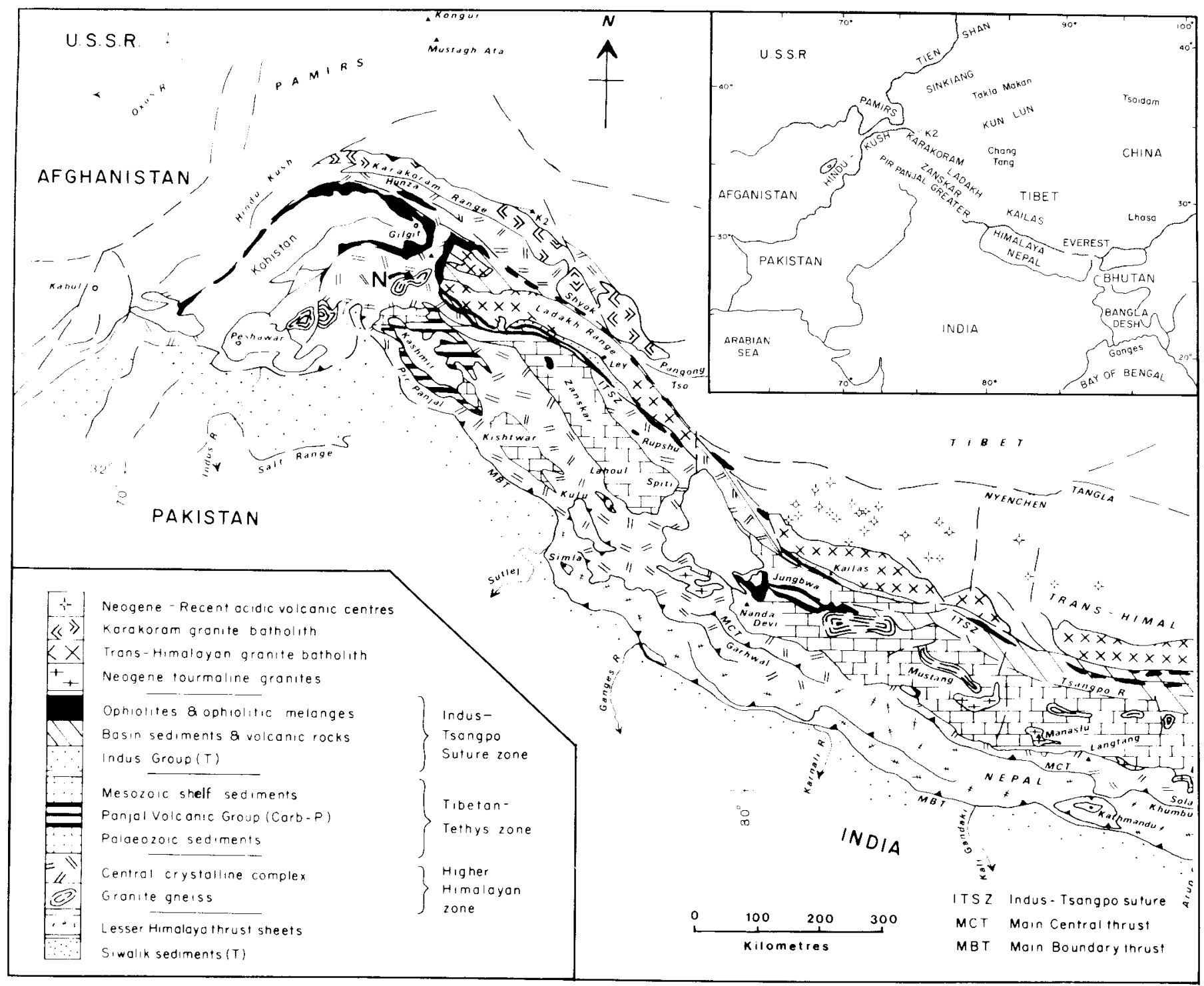

Figure 2: Geological sketch-map of the Western Himalaya and Karakoram Mountains. Inset shows major mountain ranges of Central Asia. $N-$ Nanga Parbat.

The Tethyan volcanics and Lamayuru basin sediments (Triassic to Cretaceous) are now preserved in a series of vertical or overturned thrust slices along the Indus-Tsangpo suture zone (Fig. 6). Triassic deep-water shales and "flysch" with alkali basalts, radiolarian cherts and exotic limestone blocks of Permian and Triassic age are also typical of oceanic Tethyan rocks throughout the Middle East. Strongly deformed ophiolites are present in the eastern Ladakh and southern Tibet parts of this suture zone (Thakur, 1981; Shackleton, 1981). In western Ladakh no complete ophiolite sequences have been recorded, but several mélange zones are present, consisting of strongly sheared and serpentinized harzburgites and dunites, gabbros and rodingites, tholeiitic volcanics, blueschists and deep-sea sediments.

A thick sequence of Tertiary molasse-type sediments, the Indus Group (Figs. 2, 3), can be traced along the Indus suture zone. In Ladakh they are apparently Eocene-Miocene in age and contain clasts of Ladakh granitic and volcanic rocks derived from the north, fossiliferous carbonates derived from the Zanskar shelf to the south, and radiolarites and sandstones from the Lamayuru complex (Fig. 6). A lower "autochthonous" unit of the Indus Group transgresses the Ladakh batholith at a high angle, and to the south the molasse sediments are affected by folding and thrusting. It might seem logical to correlate the continental Indus Group molasse of Ladakh with the lithogically similar and widespread Rikaze (Xigase) Group of southern Tibet, but the latter appears to be a late Cretaceous marine trench-fill deposit (Bally et al., 1980). More detailed stratigraphy and palaeontological dating will be required in order to establish exactly when marine Tethyan sedimentation ceased and continental molasse deposition began.

\section{The Kohistan-Dras Island Arc}

The Indus suture zone in northern Pakistan, south of the Karakoram, consists mainly of a structurally complicated Cretaceous island-are or mini-plate termed the Kohistan sequence (Fig. 2; Coward et al., 1982). This is composed of the stratiform, cumulate dunites, gabbros and norites of the Chilas complex, amphibolites and a thrust-bounded wedge of high-presssure granulites, the Jijal complex. Late tonalites and diorites, which may correspond to the Ladakh granitoids, intrude the Kohistan sequence which was isoclinally folded and vertically tilted during collision. The suture zone in Pakistan is bounded by two thrust faults that extend downwards to the mantle; the southern of these is associated with thrust slices of high-pressure, subduction-related glaucophane schists. 
East of the Nanga Parbat syntaxis in Ladakh (Fig. 2), the Indus suture zone contains a thick sequence of Cretaceous basalt and andesites termed the Dras volcanic sequence. These are predominantly clinopyroxene- and hornblende-phyric massive lavas with few plagioclase-phyric and nonporphyritic lithologies. They are bounded by ophiolitic mélange shears and are cut by several major shear zones containing greenschists, blueschists and serpentinite. Geochemical studies now being carried out on the immobile element covariation in these rocks show that they are consistently related to island arcs. Mafic gabbros and ultramafic cumulates with norites in the Kargil area (Fig. 6) may represent deep crustal levels of the Dras island arc.

It seems likely therefore that during the Cretaceous there was a single island arc sequence extending from Kohistan to Dras, which formed above a north-dipping subduction zone in a Tethyan marginal basin between India and Tibet.

\section{The Collision Between India and} Eurasia

Palaeomagnetic data indicate that the Indian and Asian plates were separated by distances in excess of $2000-3000 \mathrm{~km}$ during the late Cretaceous and early Tertiary (Molnar and Chen, 1978). The destruction of the Mesozoic continental shelf and margin began, probably during the latest Cretaceous (Fig. 3), with southward thrusting of Tethyan basin sediments of the Lamayuru complex over the Tibetan-Tethys Zone shelf carbonates and with obduction from a fore-arc position of the Spontang ophiolite in Zanskar (Searle, 1983). Collision of the continental margin with the Kohistan-Dras island arc closed the fore-arc basin.

From late Cretaceous to Eocene time, subduction was continuously to the north, initially beneath the Kohistan-Dras island arc and later beneath the Trans-Himalayan (LadakhKangdese) batholith. Steepening and overturning of early thrusts during the post-Eocene compression caused a phase of northward-directed backthrusting, and intense isoclinal folding. Deformation in the Zanskar shelf carbonates increases dramatically northward, and several generations of spectacular nappe formation and/of thrusting can be mapped out. The northern margin of the shelf carbonates and the Indus suture zone structures in Ladakh are inverted; thrusting is towards the north and the folds face north with axial planes dipping to the south (Searle, 1983). South of this zone all thrusts throughout the Zanskar Mountains and High Himalayas show southward transport, and all nappes are south-facing and south-verging (Fig. 5).

A preliminary structural cross-section across the Zanskar Range from the Marka Valley to Padam in the Zanskar Valley reveals at least ten major thrusts, and a first attempt at balancing suggests a minimum shortening of $100 \mathrm{~km}$, despite the little-known stratigraphy. This deformation must be Oligocene or younger, because Eocene Nummulites-bearing limestones are the youngest rocks affected. One important conclusion of this transect is that the sequence of thrusting is not a simple downward, foreland-prograding "piggy-back" sequence suggested by theoretical models (e.g. Elliott and Johnson, 1978). It is rather a highly complex sequence of overfolding, with Helvetic-type nappe formation and younger thrusts cutting up-section through an already stacked pile (Fig. 5).

There is some evidence from radiometric dating along the Trans-Himalayan batholith and the Indus-Tsangpo suture zone from Pakistan to Assam that continent-continent collision was diachronous, although considerably more stratigraphic and palaeontological dating, particularly on the Lamayuru "flyshoid" sediments and Indus-Xigase "molasse" units, is needed. Isotopic dating of ophiolites, suture zone volcanics 
and Trans-Himalayan granitoids by a number of current research teams should also put tighter constraints on tectonic interpretations.

Molnar and Tapponier (1975) and Tapponier and Molnar (1977) postulated that much of the northward movement of India was absorbed by strike-slip faulting in China. The Karakoram fault cuts the Trans-Himalayan batholith east of Rupshu and shows more than a hundred $\mathrm{km}$ of dextral shear, and the Altyn Tagh and Eastern Kun Lun faults both show large sinistral strike-slip offsets north of the Tibetan plateau. Powell and Conaghan (1973) suggested large-scale underthrusting of the whole of Tibet by the Indian plate to account for the double thickness of continental crust indicated by gravity data, while Dewey and Burke (1973) argued for basement reactivation, shortening and thickening during convergence. It is clear however that the India-Eurasia collision was a multi-stage process, probably diachronous and certainly far more complex than most previous models would suggest.

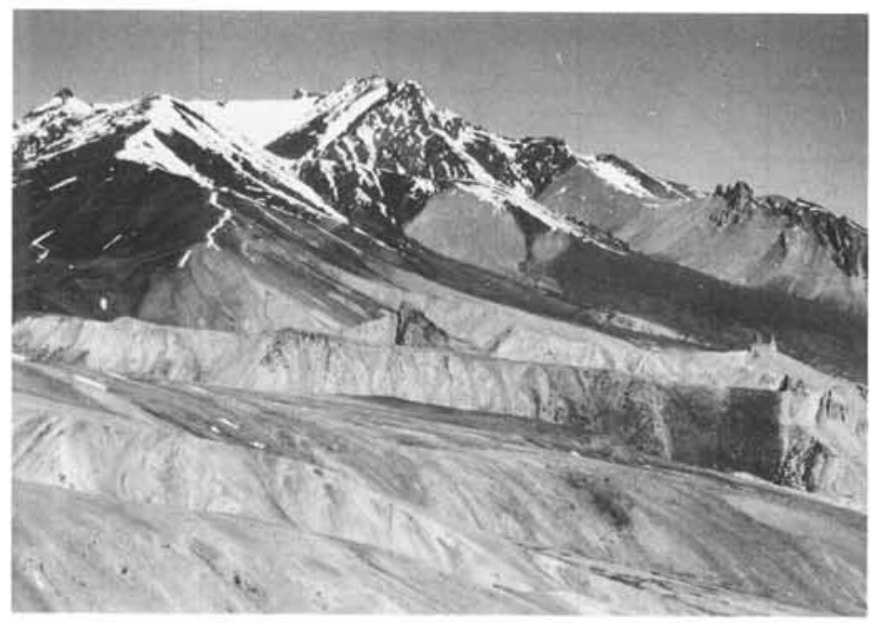

Figure 4: The Spontang ophiolite. Dark coloured harzburgites of the mantle sequence are thrust over a mélange zone and Lamayuru complex shales and turbidites with limestone blocks. Relief shown is roughly $1000 \mathrm{~m}$.

\section{The Ladakh and Karakoram Batholiths}

The Ladakh plutonic complex or its equivalent can be traced the entire length of the Himalayan arc. To the east in Kumaon and southern Tibet it is known as the Kailas tonalite (Heim and Gansser, 1939) and south of Lhasa as the Kangdese magmatic belt (Shackleton, 1981). This great TransHimalayan batholith is exposed along the $600 \mathrm{~km}$ length of the Ladakh Mountain range immediately north of the IndusTsangpo suture zone. It is composed of biotite and horn blende granodiorite with minor amounts of pyroxene diorite and late aplite veins. A unique assemblage of gabbros, norites and pyroxene-hornblende anorthosites appears to represent deep crustal levels and may be comparable to the Chilas complex in Kohistan (Coward et al., 1982).

Recent $\mathrm{Rb}-\mathrm{Sr}$ and $\mathrm{K}-\mathrm{Ar}$ analyses on Ladakh rocks by Honegger and others (1982) are in broad agreement (Fig. 3) and yield ages for the Ladakh intrusives east of Ley (Fig. 2) of 45-60 Ma and at Kargil (Fig. 5) of 70-79 Ma. Desio (1979) quotes $\mathrm{Rb}-\mathrm{Sr}$ ages from Pakistan of 48 and $38 \mathrm{Ma}$, and Brookfield and Reynolds (1981) report two ${ }^{40} \mathrm{Ar} /{ }^{39} \mathrm{Ar}$ ages of 42 and $39 \mathrm{Ma}$. Maluski and others (1982) report ${ }^{40} \mathrm{Ar} /{ }^{39} \mathrm{Ar}$ dates of 93-113 Ma for Kangdese biotite-hornblende diorites southwest of Lhasa.

These dates suggest that the Trans-Himalayan batholith is made up of a series of plutons ranging in age from AptianAlbian in Tibet to Eocene in Ladakh. The present interpretation therefore is that it represents an Andean-type coastal batholith formed by partial melting of subducted Mesozoic oceanic crust and mantle beneath Tibet. Relatively low ${ }^{87} \mathrm{Sr} /{ }^{86} \mathrm{Sr}$ initial ratios $(0.707)$ and high ${ }^{14}{ }^{3} \mathrm{Nd} /{ }^{144} \mathrm{Nd}$ ratios (0.5126) support the concept of a granitic magma derived from partial melting of subducted mantle material and con taminated by a small amount of crustal material (Allégre and Othman, 1980; Honneger et al., 1982).

The Karakoram batholith (Fig. 2) is not as well-known as the Ladakh. The two are separated by the Shyok zone, a possible suture (Gansser, 1977). The Karakoram granitoids appear to be mainly two-mica granites and seem to have younger radiometric age dates $(8-25 \mathrm{Ma})$. However, more field geochemical and isotopic work will need to be done before tectonic models can be reasonably proposed.

S

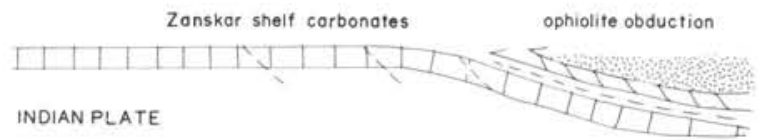

(a) Late Cretoceous

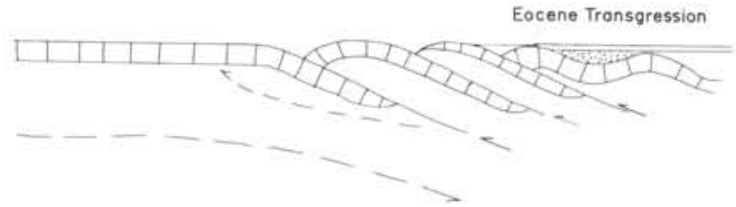

(b) Eocene

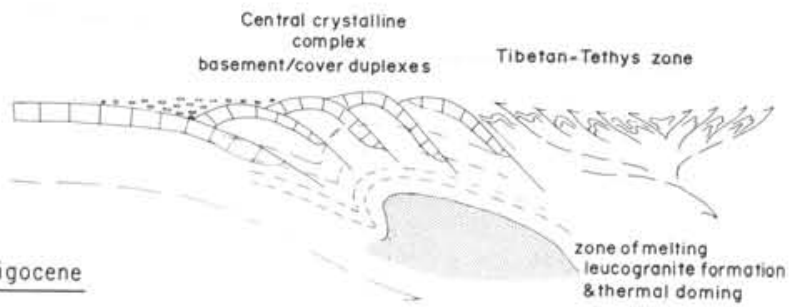

(d) Miocene

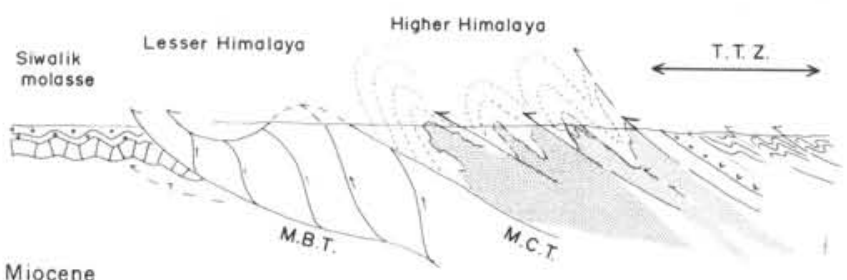

$$
\begin{aligned}
& \text { Metamorphic isograds M.C.T. Main Central thrust } \\
& \text { Leucogranites } \\
& \text { M.B.T. - Main Boundary thrust }
\end{aligned}
$$

Figure 5: Tectonic model for the evolution of the western Himalaya.

\section{Himalayan Intra-Continental Subduction}

Following the late Cretaceous-Palaeocene closing of Tethys along the Indus-Tsangpo suture zone, tectonic activity prograded southwards and continental subduction developed along a new zone of underthrusting, the Main Central Thrust (MCT on Fig. 2). The climax of Himalayan orogenic deformation, metamorphism and granitization can be related to crustal subduction during the Oligocene-Miocene along the Higher and Lesser Himalayan ranges. Leucogranites occur along the entire length of the High Himalaya (e.g. Fig. 6) and frequently form some of the topographically highest mountains (see cover photo). They include the peaks of Nanga Parbat (Pakistan), Shivling, Badrinath, and the Kedarnath 
peaks of Kumaon (India), Api, Manaslu, Himalchuli, NuptseLhotse and Makalu (Nepal), Shisha Pangma (Tibet) and Chomolhari (Bhutan).

Radiometric ages (Fig. 3) of these leucogranites at 28-12 Ma follow closely in time a thermal peak of metamorphism at 20-45 Ma in the High Himalaya (Frank et a!., 1977). Ultra-metamorphism at deeper crustal levels led to in situ anatexis, migmatization and "lit-par-lit" granitic intrusions within high-grade metasedimentary gneisses. A Barrovian regional metamorphism was superimposed on Precambrian and Palaeozoic rocks during the Oligocene. Large-scale inversion of metamorphic isograds along the MCT indicates that southverging recumbent folding and thrusting followed metamorphism. LeFort (1975) proposed an elegant hypothesis of large scale intra-continental subduction to explain the inverted metamorphism in Nepal, and in the Kulu-Lahoul Himalayas of India, Searle and Fryer (in press) have recorded at least three crustal-scale nappe structures, each showing inverted metamorphism across the Higher Himalaya (Fig. 5, section D).

High Himalayan leucogranites, though variable in composition, are all characteristic S-type granites. Muscovite, almandine and tourmaline are common magmatic phases, and leucogranites locally contain biotite, apatite and aluminosilicates, particularly kyanite. REE abundances are relatively low. Extremely high ${ }^{87} \mathrm{Sr} /{ }^{86} \mathrm{Sr}$ ratios (0.755-0.769) indicate a crustal anatectic origin, whereas a wide range of $\mathrm{Sr}$ initial ratios can be explained by melting a variety of metasedimentary rocks of the subducting Indian Shield in the presence of a large flux of volatiles and fluids (Searle and Fryer, ibid). The leucogranites appear to have been derived from a melt rich in boron, phosphorus, lithium, fluorine and $\mathrm{H}_{2} \mathrm{O}$, and the major source of heat for their generation is thought to be residual metamorphic (Barrovian) heat rather than frictional heating along major thrusts. Similar peraluminous granites, such as the Hercynian granites of Cornwall and Brittany, are richly mineralized especially with tin, tungsten and uranium; clearly the mineral potential of these High Himalayan granites is great.

LeFort (1975) and Vidal et al. (1982) estimated that only $3 \%$ of the High Himalaya in Nepal is composed of leucogranite. In contrast, the volume of Himalayan leucogranite in northwestern India appears to be $30-50 \%$. In Nepal, the MCT is the dominant structure along which metamorphic isograds are inverted; in the Indian Himalaya several major nappes with inverted isograds have been mapped. Thus, while basic processes are probably similar, considerable structural differences do occur along strike in the Higher Himalaya. The beauty of these mountains is that because of thrusting, folding, tilting and deep erosion, the results of deep crustal processes normally not exposed can be clearly studied.

\section{Quaternary Extension on the Tibetan Plateau}

Fault-plane solutions of earthquakes across the Tibetan plateau indicate a vertical maximum principal stress and a of N.W. India. minimum principal stress that is east-west. North-south shortening occurs throughout the Himalaya, and Pleistocene to Recent thrusts with southward movement are active along

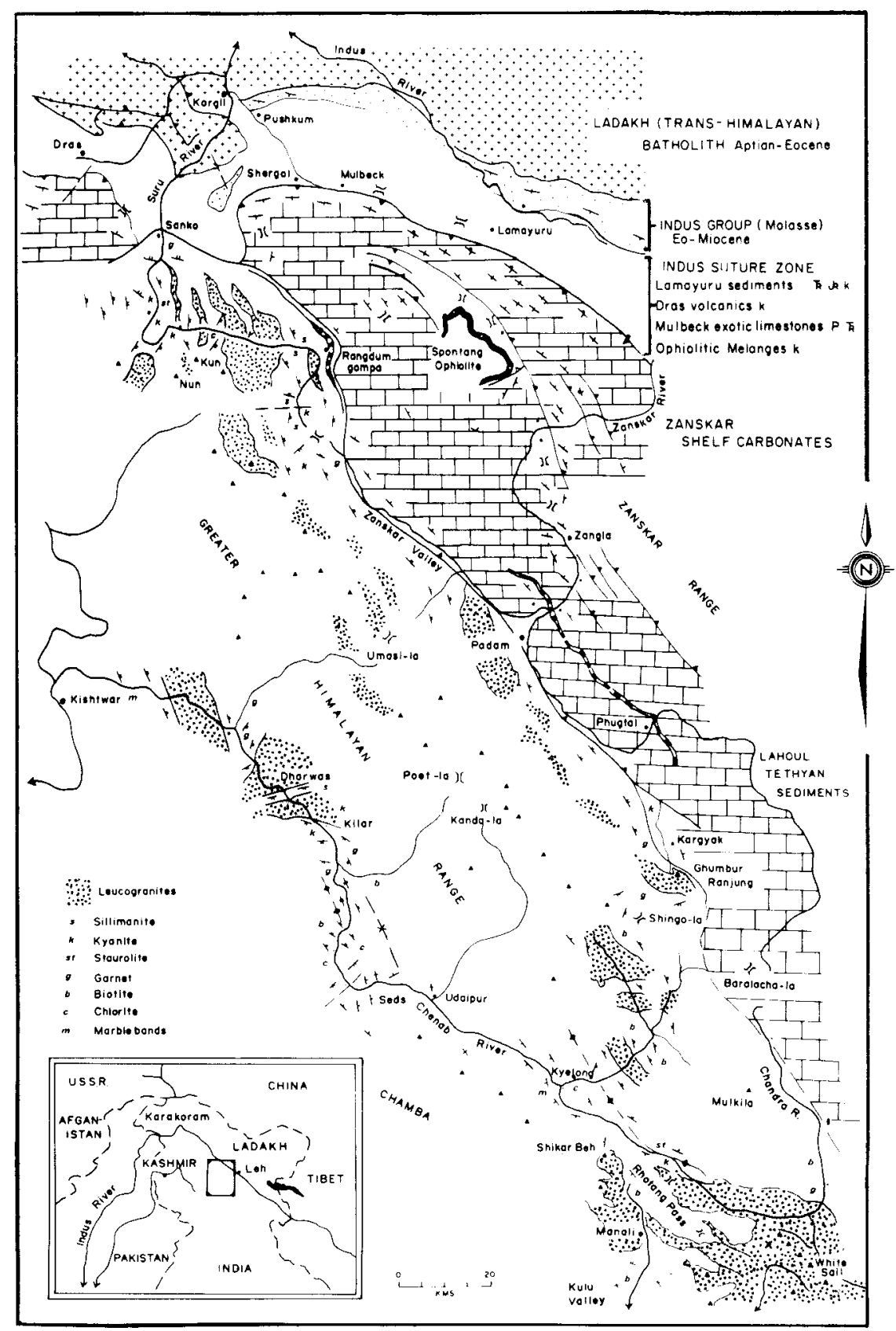

Figure 6 : Geological sketch-map of the central crystalline complex, TibetanTethys and Indus suture zones in the Ladakh, Zanskar, Kishtwar and Kulu Himalaya

the Main Boundary Thrust (MBT on Fig. 2). However, the most recent deformations in Tibet are related, surprisingly, to an east-west extension of the crust. LANDSAT photo interpretation and some recent fieldwork (Tapponier and Molnar, 1977; Tapponier et al., 1981) show the existence of a number of north-south normal faults, some of which cut moraines and post-glacial terraces. Many spectacular geothermal geysers find access to the surface along these $\mathrm{N}-\mathrm{S}$ fault systems.

\section{Conclusions}

In summary, a southward progradation of underthrusting and subduction took place in the Himalaya from the late Cre- 
taceous Indus-Tsangpo suture zone to the Oligocene-Miocene Main Central Thrust and the Pliocene-Pleistocene Main Boundary Thrust. The Eocene Ladakh (Trans-Himalayan) biotitehornblende granite batholith can be related to subduction along the Indus-Tsangpo suture zone, and the Miocene leucogranites to crustal melting along the Higher Himalaya.

Southward-directed thrusting in the Tibetan Tethys and Indus suture zones accompanied collapse of the continental margin and ophiolite emplacement in the late Cretaceous. Later Tertiary compression caused intense folding, overturning and a phase of northward-directed backthrusting along the Indus suture zone and the northern margin of the Tibetan-Tethys zone. Structural inversion of metamorphic zones up to sillimanite grade in the Higher Himalayan Ranges is related to mid-Tertiary thrusting and nappe formation, which caused inversion of isograds around crustal-scale south-verging nappes.

Whereas older tectonic models were based largely on speculation, they can now be adjusted in the light of more recent work to fit current detailed structural, stratigraphic, geochemical, isotopic and geochronological information. There is no reason to suppose that eventually this most recent and most spectacular mountain range on Earth should not one day become the best understood geologically. The geotectonic processes involved in the evolution of the Himalayas could then be used to extrapolate to other older orogenic belts that are either less well exposed or eroded down to deeper levels.

\section{Acknowledgements}

I am grateful for many discussions with colleagues at Memorial University of Newfoundland and the Wadia Institute of Himalayan Geology, Dehra Dun. I particularly thank my friends and trekking companions during three expeditions, Rintzing Tanta and Sring Norbu lama of Padam, Fida Hussein of Ley, Sonam Targis of Marka and Tschering Tukten of Sani, Zanskar.

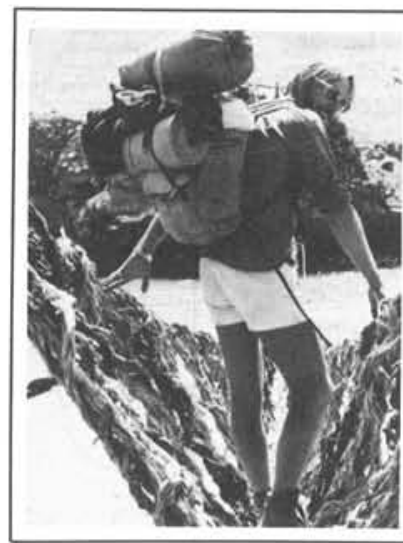

Michael P. Searle obtained his doctorate at the Open University, U.K., where he specialized in the study of sub-ophiolite rocks in the Oman Mountains. He is now extending his research into the Himalaya from a base at the Department of Earth Sciences, Memorial University, St. John's, Nfld, Canada.

\section{References}

Allégre, C.J. and Ben Othman, D., 1980. Nd-Sr isotopic relationship in granitoid rocks and continental crust development: a chemical approach to orogenesis. Nature 286 , no. 5771 , p. 335-42.

Bally, A.W., Allen, C.R., Geyer, R.B., Hamilton, W.B., Hopson, C.A., Molnar, P.H., Oliver, J.E., Opdyke, N.D., Plafker, G., Wu, F.T., 1980. Notes on the Geology of Tibet and Adjacent areas - Report of the American Plate Tectonics Delegation to the People's Republic of China. U.S. Geological Survey Open File Report 80-501, 101p.

Brookfield, M.E. and Reynolds, P.H., 1981. Late Cretaceous emplacement of the Indus suture zone ophiolitic mélanges and an Eocene-Oligocene magmatic arc on the northern edge of the Indian plate. Earth and Planetary Science Letters, v. 55, no. 1, p. 157-162.

Coward, M.P., Jan, M.Q., Rex, D., Tarney, J., Thirlwall, M. and Windley, B.F., 1982. Geotectonic Framework of the Himalaya of $\mathrm{N}$. Pakistan. Journal of the Geological Society of London 139, Part 3, p. 299-308.

Desio, A., 1979. Geological evolution of the Karakoram. In: Farah, A. and DeJong, K.A. (eds.), Geodynamics of Pakistan, Geologica! Survey of Pakistan, Quetta, p. 111-124.

Dewey, J.F. and Burke, K.C.A., 1973. Tibetan, Variscan and Precambrian basement reactivation: products of continental collision. Journal of Geology, v. 81, no. 6, p. 683-92.

Elliott, D. and Johnson, M.R.W., 1978. Discussion of structures found in thrust belts. Journal of the Geological Society of London, v. 135, Part 2, p. 259-260.

Frank, W., Gansser, A. and Trommsdorff, V., 1977. Geological observations in the Ladakh area (Himalayas) - a preliminary report. Schweizerische Mineralogische und Petrographische Mitteilungen, vo. 57 , no. 1, p. 89. 113.

Fuchs, G., 1979. On the Geology of Western Ladakh. Jahrbuch der Geologischen Bundestalt, v. 122, Part 2, p. 513-40.

Gansser, A., 1964. Geology of the Himalayas. London: Wiley Interscience Publishers, 289p.

Gansser, A., 1977. The great suture zone between Himalaya and Tibet, a preliminary account. In: Science Terre: Himalaya CNRS 268, v. 2, p. 181-91.

Gupta, V.J. and Kumar, S., 1975. Geology of Ladakh, Lahqul and Spiti regions of Himalaya with special reference to the stratigraphic position of flysch deposits. Geologische Rundschau, v. 64, no. 2, p. 540-63.

Heim, A. and Gansser, A., 1939. Central Himalaya - Geological observations of the Swiss Expedition 1936. Reprinted Hindustan Publishing Corp., Delhi, 1975, 245p.

Honegger, K., Dietrich, V., Frank, W., Gansser, A., Thommi, M. and Trommsdorff, V., 1982. Magmatism and metamorphism in the Ladakh Himalayas (the Indus-Tsangpo suture zone). Earth and Planetary Science Letters, v. 60, p. 253-292.

LeFort, P., 1975. Himalayas: the collided range. Present knowledge of the continental arc. American Journal of Science, 275A, p. $1-44$.

Maluski, H., Proust, F. and Xiao, X.C., 1982. ${ }^{39} \mathrm{Ar} /{ }^{40} \mathrm{Ar}$ dating of the trans-Himalayan calc-alkaline magmatism of southern Tibet. Nature, v. 298, p. 152-154.

Molnar, P. and Tapponnier, P., 1975. Cenozoic tectonics of Asia: effects of continental collision. Science, v. 189 , no. 4201 , p. 419 26.

Molnar, P. and Chen Wang-ping, 1978. Evidence of large Cainozoic crustal shortening
of Asia. Nature, v. 273 , no. 5659 , p. 218 220.

Nicholas, A., Girardeau, J., Marcoux, J., Dupre, B., Wang Xibin, Cau Yougong, Zheng Haixiang and Xiao Xuchang, 1981. The Xigaze ophiolite (Tibet): a peculiar oceanic lithosphere. Nature, v. 294 , no. 5840 , p. $414-417$.

Norin, E., 1946. Geological explorations in western Tibet: Report on Sino-Swedish Expedition 29, Stockholm.

Powell, C.McA. and Conaghan,, P.J., 1973. Plate tectonics and the Himalayas. Earth and Planetary Science Letters, v. 20, no. 1, p. $1-12$.

Powell, C.MCA. and Conaghan, P.J., 1975. Tectonic models of the Tibetan plateau. Geology, v.3, no. 12, p. 727-31.

Searle, M.P., 1983. Stratigraphy structure and evolution of the Tibetan-Tethys zone in Zanskar and the Indus suture zone in the Ladakh Himalaya. Transactions of the Royal Society of Edinburgh: Earth Sciences, v. 73, Part 4, p. 205-219.

Searle, M.P. and Fryer, B.J., in press. Garnet, tourmaline and muscovite-bearing leucogranites of the Higher Himalaya from Zanskar, Kulu, Lahoul and Kashmir. GeoZanskar, Kulu, Lahoul an
logical Society of London.

Shackleton, R.M., 1981. Structure of Southern Tibet: report on a traverse from Lhasa to Khatmandu organised by Academia Sinica. Journal of Structural Geology, v. 3, no. 1, p. 97-105.

Shah, S.K., Sharma, M.L., Gergan, J.T. and Tara, C.S., 1976. Stratigraphy and structure of the western part of the Indus suture belt, Ladakh, northwest India. Himalayan Geology, v. 6, p. 543-56.

Srikantia, S.V. and Razdan, M.L., 1980. Geology of part of Central Ladakh Himalaya with particular reference to Indus Tectonic zone. Journal of the Geological Society of India, v. 21, no. 11, p. 523-45.

Tapponier, P. and Molnar, P., 1977. Active faulting and Cenozoic tectonics in China. Journal of Geophysical Research, v. 82 , no. 20, p. 2905-2930.

Tapponier, P. et al., 1981. The Tibetan side of the India-Eurasia collision. Nature, v. 294, no. 5840 , p. $405-410$.

Tahirkheli, R.A.K., 1979. Geology of Kohistan, Karakoram Himalaya, northern Pakistan. In: Tahirkheli, R.A.K. and Jan, M.Q. (eds.), Geological Bulletin University Peshawar Special Issue v. 11, no. 1, p. 1-30.

Thakur, V.C., 1981. Regional framework and geodynamic evolution of the Indus-Tsangpo suture zone in the Ladakh Himalayas. Transactions of the Royal Society of Edinburgh. Earth Sciences, v. 72, no. 2, p. 89-97.

Vidal, P.H., Cocherie, A. and LeFort, P., 1982. Geochemical investigations of the origin of the Manaslu leucogranite (Himalaya, Nepal). Geochimica et Cosmochimica Acta, v. 46 , no. 11, p. 2279-2292.

Wadia, D.N., 1953. Geology of India. 3rd Edition, Macmillan, London, $531 \mathrm{p}$. 